ISSN: 2322 - 0902 (P)

ISSN: 2322 - 0910 (0)

\author{
Research Article
}

\title{
CLINICAL EVALUATION OF EFFICACY OF KUSTHADI CHURNA WITH UDUMBARADI TAILA IN THE MANAGEMENT OF KARNINI YONIVYAPAD W.S.R. TO CERVICAL EROSION
}

\author{
Chaurasia Ranju Kumari'1*, C.M. Jain², B. Pushplatha ${ }^{3}$, K. Bharathi ${ }^{4}$ \\ ${ }^{* 1}$ P.G. Scholar, ${ }^{2}$ Head of Department, ${ }^{3}$ Assistant Professor, Department of Prasuti-Stree Roga, NIA, Jaipur. \\ ${ }^{4}$ Research Officer (Ayurveda), National Ayurveda Research Institute for Vector Born Diseases (CCRAS), Viajayawada.
}

\begin{abstract}
Karnini yonivyapad is one of the gynaecological disorders described in Ayurveda under the umbrella of the Yonivyapad. According to the signs and symptoms, it is more nearer to the benign lesion cervical erosion, which occurs due to the replacement of the stratified squamous epithelium of the portiovaginalis by the columnar epithelium of endocervix. The treatment is designed to destruct the columnar epithelium by any method and to promote the re-epithelization of the squamous tissues. Keeping this point in view, the present clinical trial is taken up with the aim of clinical evaluation of efficacy of Kusthadi churna with Udumbaradi taila in the management of Karnini yonivyapad (cervical erosion). Kusthadi churna along with Yonipichu with Udumbaradi taila group-A, and group-B only Udumbaradi taila yonipichu, and results were assessed on the basis of the epithelization of erosion and improvement in the symptoms. The study reveals that the mixed therapy group showed better results than the group of single drug.
\end{abstract}

KEYWORDS: Karnini, Cervical Erosion, Yonivyapad, Benign Lesion.

\section{INTRODUCTION}

When looking into the Ayurvedic literature it becomes evident that all the gynaecological disorders are included in the Yonivyapad. No direct reference regarding the Karnini yonivyapad is present in the text which make it's resemblance with cervical erosion. However, considering the pathology and main symptoms of cervical erosion, discharge and erosion (like Karnikamuscular enlargement like tuber) at the site of cervix and the treatment mentioned in the Ayurvedic texts, it can be correlated with the Karnini yonivyapad. On the basis of the etiology we can conclude that Karnini is chiefly the disease of reproductive age group, and is more commonly seen in sexually active female.

Cervical erosion is one of the commonest gynaecological conditions seen in the OPDs. About $80 \%$ women suffer from the cervical erosion i.e. benign condition of female genital tract during their life time, where stratified squamous epithelium of the portiovaginalis is replaced the by the columnar epithelium of endocervix. It is not an area denuded of epithelium as its name implies. It appears as red velvet like area or rawlooking granular appearance on the ectocervix when visualized with speculum. In cervical erosion the cervix is not eroded and there is no ulceration, the reason to make cervix look red and raw is that the columnar epithelium is much thinner than the squamous epithelium and so the underlying blood vessels seen more clearly from outside. Although the cardinal symptom of the disease is excessive vaginal discharge, but often the long term sequel of the disease like lower abdominal pain, lower back ache, fatigue, joint pain etc become too much troublesome to the patients and start affecting their daily routine. So they visit the physician with this problem posing them as their chief complaint. In chronic stage it can show malignant changes. So treatment must be started as soon as the diagnosis of erosion is confirmed. Though it is not fatal, yet the long term association with the disease and a number of symptoms both related to the genitourinary system as well as psychological imbalance in the patient needs attention.

Nidana sevan vitiate the Vata (Apana vayu) there by Kha-vaigunya takes place in the Artavaha strotas so here the vitiated Vata get mixed with Kapha dosha and Rakta dhatu and in this way the Dosha dushya Sammurchana is completed. Adhisthana of disease is the Garbhashaya dwara mukha i.e. cervix, so in the stage of Vyakta avashtha, Karnika is formed here which is the cardinal symptom of Karnini yonivyapada. So the Ayurvedic treatment having the properties of Lekhana, Sodhana, Ropana, Stambhana, Kaphaghna can effectively cure this disease. Kapha-vata shamak doshakarma of drugs in the trial group were responsible for Samprapti vighatana of Karnini yonivyapada as vitiation of Vata Kapha dosha is responsible for this disease.

Over all aim of the treatment is to destruct the over grown columnar epithelium by the use of topical drugs. After the destruction of the columnar epithelium the normal squamous epithelium from the basal cell grows and heals the erosion. To enhance this process of epithelization, drugs which help in the healing and regeneration of the tissue were used. With this background, drugs named 'Kusthadi churna (ingredients 
are same as Kusthadivarti of Caraka Cikitsa 30/109) for local application on the eroded area for about 10 minutes, and after washing it with sterile water a Pichu soaked in the Udumbaradi taila was applied in the vagina and left inside for about 4-6 hours. A comparative study has been made to see the effect of the combination of Kusthadi churna with Udumbaradi tail and Udumbaradi taila pichu alone in cervical erosion. Kusthadi churna (all the content of Kusthadivarti Ch. Chi 30/109) drugs were collected, dried under shade, and powder prepared with the help of grinder, trituration of this Churna was done with Vasta mutra (goat's urine) for twenty one times and dried under shade every time. Udumbaradi Taila (Ca. Ci. 30/73-76) was prepared according to 'Taila Paka Vidhi' mentioned in Sharangdhara Samhita. Paka was done till 5 days (daily for two hours on mild heat) till the Samyaka lakshana of Madhyama paka were obtained.

\section{AIMS AND OBJECTIVE:}

1. To compare the clinical efficacy of combination of Kusthadi churna and Udumbaradi taila pichu and Udumbaradi taila pichu alone in the management of Karnini yonivyapad (cervical erosion) and to assess the reduction in the symptoms of both subjective as well as objective criteria.

2. To study any side effect related to the drug.

3. To establish the Ayurvedic treatise in the management of cervical erosion.

\section{MATERIAL AND METHODS}

Study design-Randomized control trial, Open trial, at a single centre.

\section{Selection of cases}

- Total 30 clinically diagnosed and confirmed cases of cervical erosion were registered for the present clinical trial, from the O.P.D./I.P.D. of P.G. Department of Prasuti-Stree Roga, National Institute of Ayurveda (N.I.A.) Hospital, Jaipur.

- Those patients were only selected who had given 'voluntary informed consent'.

- Selected patients were examined thoroughly with the help of proforma especially designed for the study.

\section{Inclusion criteria}

- Clinically diagnosed and confirmed patients of cervical erosion who were married and having the age in between 18-45 years, were registered for the present clinical trial.

- Patient willing to go through trial.

\section{Exclusion criteria}

Women of age less than 18 and above the age of 45 years, Adolescent girl, Pregnant women, patients suffering with any organic pathology of uterus and adnexae like cervical carcinoma, any malignant growth, cervical fibroids, endometrosis etc. Patient who is having coagulation disorders; second and third degree uterine prolapsed; HIV, VDRL, HBsAg positive patients; patients who are using I.U.C.D.; Patients having any severe systemic illness like Genital tuberculosis, Diabetes mellitus, Congestive cardiac failure etc.

\section{Grouping of Patients:}

Group A: Kusthadi churna as local application on eroded area and Udumbaradi Tail Pich was applied after application of Kusthadi curn- both were given for 14days for maximum two consecutive menstrual cycles.

Group B: Udumbaradi taila pichu administered for fourteen days for maximum two consecutive cycles after the bleeding phase of menstrual cycle.

Selected patients were allocated randomly into two groups. Patients were called for drug application on the $2^{\text {nd }}$ or $3^{\text {rd }}$ day after clearance of menstrual flow. Abstinence from sex was advised during the period of treatment.

\section{Investigations:}

Blood-Hemoglobin, T.L.C, D.L.C, E.S.R, R.B.S, HIV, HBsAg, VDRL, MT.

Urine - Routine and microscopic examination

Pap's smear for cervical cytology.

All investigations were done before and after the completion of trial.

\section{Assessment Criteria}

\section{Amount of Vaginal Discharge}

$0(-) \quad$ : Absent

$1(+)$ : Persistent vulvae moistening only.

$2(++)$ : Persistent staining of undergarments

$3(+++)$ : Profuse / heavy and needs applying of vulval pads

2. Pruritis vulvae

$\begin{array}{ll}0(-) & : \text { Absent } \\ 1(+) & : \text { Itching occasionally } \\ 2(++) & : \text { Itching during day \& night with } \\ & \text { disturbed sleep } \\ 3(+++): \text { Intolerable itching } & \end{array}$

3. Dysmenorrhoea

$0(-) \quad$ : Absent

$1(+)$ : Mild pain throughout the day but relieved by rest

$2(++)$ : Moderate pain interfering physical activity \& not relieved by rest

$3(+++)$ : pain interfering physical activity \& relieved by taking analgesics

\section{Pain in lower abdomen}
$0(-) \quad$ : Absent
$1(+)$ : Mild pain throughout the day but relieved by rest
$2(++)$ : Moderate pain interfering physical activity \& not relieved by rest
$3(+++)$ : pain interfering physical activity \& relieved by taking analgesics 


\section{Fatigue}

$0(-) \quad$ : Absent

$1(+) \quad$ : Occasionally on doing heavy work

$2(++) \quad$ : After doing extra work

$3(+++)$ : Even without doing work

\section{Joint Pain}

$0(-) \quad$ : Absent

$1(+) \quad$ : Pain increase on exertion, relieved by rest

$2(++)$ : Pain increase on exertion, not relieved by rest

$3(+++)$ : Day \& night \& relieved by pain killers \& rest

\section{Lower Backache}

$0(-) \quad$ : Absent

$1(+) \quad$ : Pain increase on exertion, relieved by rest

$2(++) \quad$ : Pain increase on exertion, not relieved by rest

$3(+++)$ : Day \& night \& relieved by pain killers \& rest

\section{Erosion on cervix}

$$
\begin{array}{ll}
0(-) & : \text { No erosion } \\
1(+) & : \text { Erosion covering less than } 25 \% \text { area } \\
& \text { of cervix. } \\
2(++) & : \text { Erosion covering, } 26 \text { to } 50 \% \\
3(+++) & : \text { Erosion covering } 51 \text { to } 75 \% \text { as } \\
4(+++) & : \text { Erosion covering } 75 \% \text { to above }
\end{array}
$$

\section{B. Objective parameters}

1. Extent of cervical erosion: Cervix was measured at six to eight different angles with modified compass and OBSERVATION AND RESULTS measurements were marked on a graph paper having 100 divisions in one square inch and shape and size of cervix was drawn. Now the area covered with erosion was also measured and drawn on the graph paper over diagram of cervix. The squares of graph paper covered with cervix and erosion were counted separately and percent area of cervix covered with erosion was calculated by following formula.

No. of square covered with erosion

$$
\longrightarrow \text { X } 100
$$

No. of square covered with cervix

\section{Oozing of blood on rubbing with a gauze piece}

$0(-) \quad$ : Absent

$1(+) \quad$ : 3-5 pin points of oozing on rubbing with gauze

$2(++):>5$ pin points of oozing on rubbing with gauze

$3(+++)$ : Excessive oozing / bleeding on touching with gauze

Overall effect of therapies: No relief- $0 \%$, Mild relief25\%, Moderate Relief-26-50\%, Significant relief-51-75\%, Excellent Relief-76-100\%

Statistical analysis: All the information which were based on various parameters were gathered and statistical study was carried out in terms of mean (x) standard deviation (S.D), standard error (S.E.) paired test. (t. value) Finally result were shown in terms of

\begin{tabular}{|c|c|c|c|c|c|c|c|c|c|}
\hline \multirow[b]{2}{*}{ S No. } & \multirow{2}{*}{ Symptoms } & \multicolumn{2}{|c|}{ Mean } & \multirow{2}{*}{ Dif } & \multirow{2}{*}{$\begin{array}{c}\% \text { of } \\
\text { Change }\end{array}$} & \multirow{2}{*}{ SD } & \multirow[b]{2}{*}{ SE } & \multirow{2}{*}{$\mathbf{P}$} & \multirow{2}{*}{ Results } \\
\hline & & BT & AT & & & & & & \\
\hline 1. & Vaginal discharge & 2.2 & 0.53 & 1.66 & 75.75 & 0.488 & 0.126 & $<0.0001$ & E.S \\
\hline 2. & Dysmenorrhoea & 0.8 & 0.2 & 0.6 & 75 & 0.91 & 0.23 & 0.0625 & NQS. \\
\hline 3. & Pruritus Vulvae & 0.26 & 0.06 & 0.2 & 75 & 0.56 & 0.14 & 0.50 & N.S. \\
\hline 4. & Lower abdominal pain & 1.33 & 0.26 & 1.06 & 80 & 1.09 & 0.28 & .0039 & V.S. \\
\hline 5. & Fatigue & 2.46 & 1.46 & 1 & 40.54 & 0.84 & 0.21 & 0.0024 & V.S. \\
\hline 6. & Joint Pain & 0.933 & 0.5 & 0.4 & 42.85 & 0.63 & 1.163 & 0.0625 & $\mathrm{NQS}$ \\
\hline 7. & Lower Backache & 2.2 & 1.2 & 1 & 45.45 & 0.84 & 0.21 & 0.001 & E.S. \\
\hline
\end{tabular}
probability $(\mathrm{P})$ as $\mathrm{p}>0.05$ - Insignificant, $\mathrm{p}<0.05$ Significant, $\mathrm{p}<0.01$ and $\mathrm{P}<0.001$ - Highly significant.

Table I: Shows the incidence of signs and symptoms of cervical erosion

\begin{tabular}{|l|c|c|c|c|}
\hline Sign and Symptoms & Group A & Group B & Total & Percentage \\
\hline a) Vaginal Discharge & 15 & 15 & 30 & $100 \%$ \\
\hline b) Pruritus vulvae & 2 & 6 & 8 & $26.66 \%$ \\
\hline c) Dysmenorrhoea & 5 & 7 & 12 & $40 \%$ \\
\hline d) Pain in lower abdomen & 10 & 11 & 21 & $70 \%$ \\
\hline e) Fatigue & 12 & 15 & 27 & $90 \%$ \\
\hline f) Joint pain & 6 & 7 & 13 & $43.33 \%$ \\
\hline g) Low back pain & 13 & 12 & 25 & $83.33 \%$ \\
\hline h) Erosion on cervix & 15 & 15 & 30 & $100 \%$ \\
\hline i) Oozing of blood on rubbing with gauze & 15 & 15 & 30 & $100 \%$ \\
\hline
\end{tabular}

\section{Results}

Table-II: Shows the pattern of Clinical recovery in various symptoms in Group A $(n=15)$

N.S = Non significant, E.S = extremely significant, NQS= Not quite significant, V.S = Very significant 
Int. J. Ayur. Pharma Research, 2015;3(12):58-64

Table - III: Shows the pattern of clinical recovery in various objective parameters in Group A (n=15)

\begin{tabular}{|c|c|c|c|c|c|c|c|c|c|c|}
\hline \multirow{2}{*}{ S No. } & \multirow{2}{*}{ Symptoms } & \multicolumn{2}{|c|}{ Mean } & \multirow{2}{*}{ Dif. } & \multirow{2}{*}{$\begin{array}{c}\% \text { of } \\
\text { Change }\end{array}$} & \multirow{2}{*}{ SD } & \multirow{2}{*}{$\mathbf{S E}$} & \multirow[b]{2}{*}{ t } & \multirow{2}{*}{$\mathbf{P}$} & \multirow{2}{*}{ Results } \\
\hline & & BT & AT & & & & & & & \\
\hline 1. & Extent of erosion & 1.66 & 0.53 & 1.13 & 68 & 0.83 & 0.21 & 5.26 & 0.0001 & E.S. \\
\hline 2. & $\begin{array}{l}\text { Oozing of blood on rubbing } \\
\text { with a gauze piece. }\end{array}$ & 1.6 & 0.466 & 0.13 & 70.833 & 0.51 & 0.13 & 8.5 & $<0.0001$ & E.S. \\
\hline
\end{tabular}

N.S = Non significant, E.S = extremely significant, $N Q S=$ Not quite significant, V.S = Very significant

Table- IV: Shows the pattern of clinical recovery in various symptoms in Group $B(n=15)$

\begin{tabular}{|l|l|c|c|c|c|c|c|c|c|}
\hline \multirow{2}{*}{ S No. } & \multicolumn{1}{|c|}{ Symptoms } & \multicolumn{2}{|c|}{ Mean } & \multirow{2}{*}{ Dif. } & $\begin{array}{c}\text { \% of } \\
\text { Change }\end{array}$ & \multirow{2}{*}{ SD } & \multirow{2}{*}{ SE } & \multirow{2}{*}{ P } & \multirow{2}{*}{ Results } \\
\cline { 3 - 10 } & & BT & AT & & & & \\
\hline 1. & Vaginal discharge & 2.4 & 1.53 & 0.86 & 36.11 & 0.63 & 0.16 & 0.001 & E.S. \\
\hline 2. & Dysmenorrhoea & 1.2 & 0.5 & 0.8 & 57.89 & 0.96 & 0.24 & 0.0156 & S. \\
\hline 3. & Pruritus Vulvae & 1.26 & 0.6 & 0.66 & 52 & 1.2 & 0.31 & 0.0625 & NQS. \\
\hline 4. & Lower abdominal pain & 1.67 & 0.6 & 1.06 & 64 & 0.96 & 0.24 & 0.0020 & V.S. \\
\hline 5. & Fatigue & 2.3 & 1.5 & 0.8 & 34.28 & 0.82 & 0.21 & 0.0010 & E.S. \\
\hline 6. & Joint Pain & 0.86 & 0.26 & 0.6 & 69 & 0.82 & 0.21 & 0.0313 & S. \\
\hline 7. & Lower Backache & 1.46 & 0.53 & 0.93 & 63.63 & 0.79 & 0.20 & 0.0020 & V.S. \\
\hline
\end{tabular}

N.S = Non significant, E.S = extremely significant, NQS= Not quite significant, V.S = Very significant

Table -V: Shows the pattern of clinical recovery in various objective parameters in Group-B $(n=15)$.

\begin{tabular}{|c|c|c|c|c|c|c|c|c|c|c|}
\hline \multirow{2}{*}{ S No. } & \multirow{2}{*}{ Symptoms } & \multicolumn{2}{|c|}{ Mean } & \multirow{2}{*}{ Dif. } & \multirow{2}{*}{$\begin{array}{c}\text { \% of } \\
\text { Change }\end{array}$} & \multirow{2}{*}{ SD } & \multirow{2}{*}{ SE } & \multirow{2}{*}{ t } & & \multirow{2}{*}{ Results } \\
\hline & & BT & AT & & & & & & & \\
\hline 1. & Extent of $\mathrm{e}$ & 1.86 & 1.26 & 0.6 & 32.14 & 73 & .19 & 3.15 & 0.0070 & V.S. \\
\hline 2. & $\begin{array}{l}\text { Oozing of blood on rubbing } \\
\text { with a gauze piece. }\end{array}$ & 1.467 & 1.067 & 0.4 & 27.27 & 0.63 & 0.16 & 2.44 & 0.0 & S. \\
\hline
\end{tabular}

N.S = Non significant, E.S = extremely significant, NQS= Not quite significant, V.S = Very significant

\section{Fiure No.1: Pattern of changes in subjective and objective criteria of Group A}

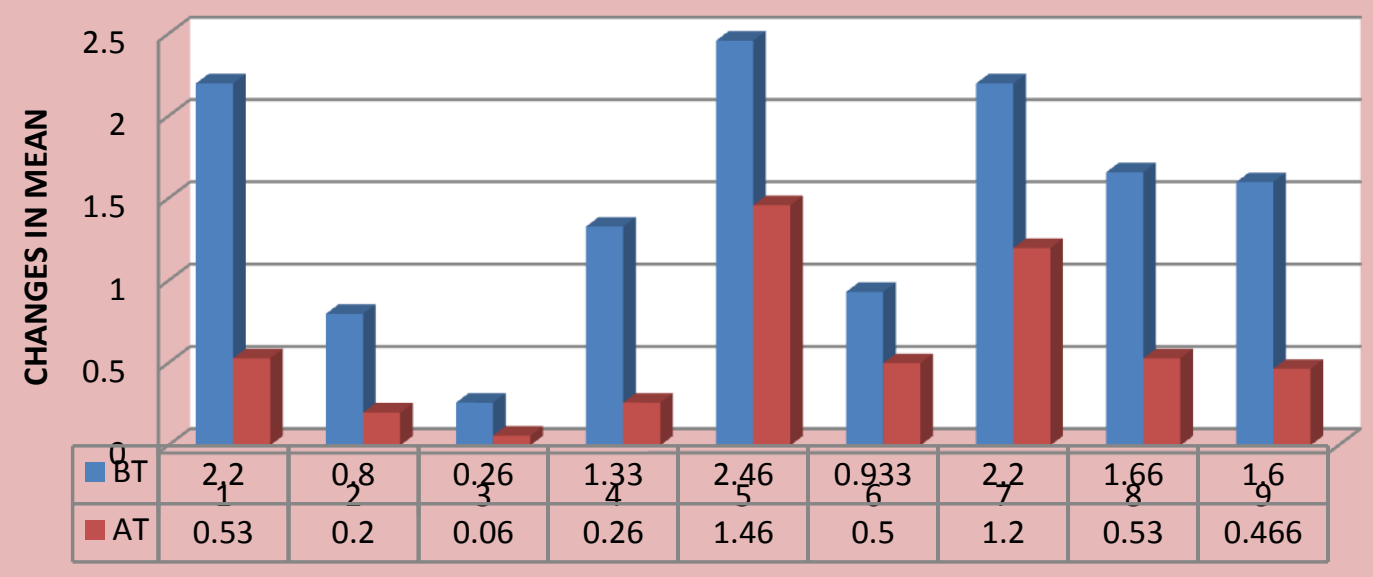




\section{Figure No.2: Pattern of changes in subjective and objective criteria of Group B}

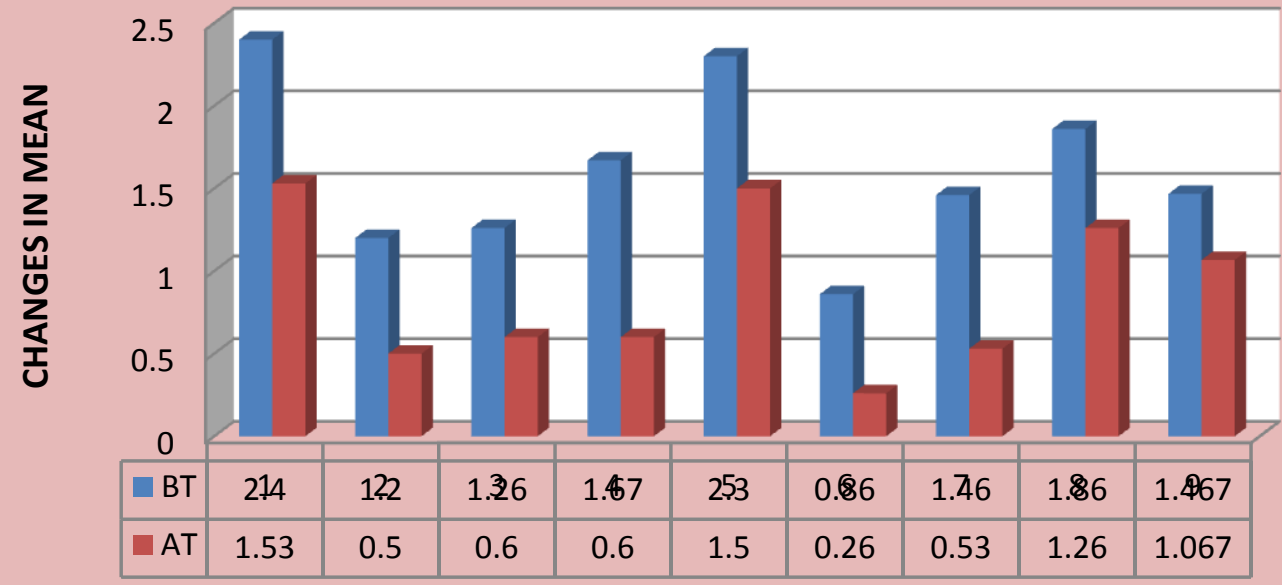

Table No.VI: Shows the percentage of improvement of symptoms and signs in both groups

\begin{tabular}{|l|l|l|}
\hline \multirow{2}{*}{ Cardinal symptoms } & \multicolumn{2}{|l|}{ Result in percentage } \\
\cline { 2 - 3 } & Group A & Group B \\
\hline Vaginal discharge & $75.75 \%$ & $36.11 \%$ \\
\hline Dysmenorrhoea & $75.00 \%$ & $57.89 \%$ \\
\hline Pruritis Vulvae & $75.00 \%$ & $52.00 \%$ \\
\hline Lower abdominal pain & $80.00 \%$ & $64.00 \%$ \\
\hline Fatigue & $40.54 \%$ & $34.28 \%$ \\
\hline Joint Pain & $42.85 \%$ & $69.00 \%$ \\
\hline Lower Backache & $45.45 \%$ & $63.63 \%$ \\
\hline Extent of erosion & $68.00 \%$ & $32.14 \%$ \\
\hline Oozing of blood on rubbing with gauze & $70.83 \%$ & $27.27 \%$ \\
\hline
\end{tabular}

Graph No.4: Overall effect of therapy

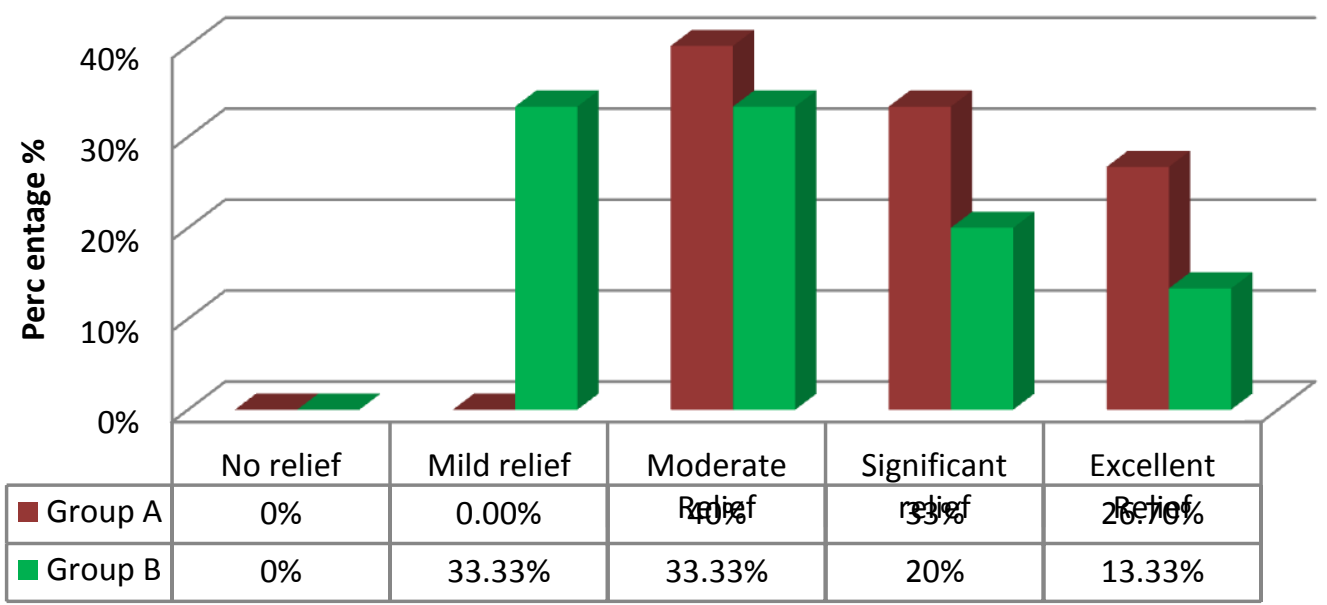

\section{DISCUSSION}

\section{Discussion on demographic data}

The maximum number of patients was in the age group of 31-35 (36.67\%). This incidence of age manifest that the disease mainly affects the reproductive age group as the period is the greater sexual activity, child birth, abortion, trauma, and infections. 100\% women were married. This shows that the disease is more prone to the sexually active females. Maximum patients belong to Hindu religion i.e. $63.33 \%$, may be due to Hindu 
dominant population. Maximum 73.33\% were housewife, this may be due to they often neglect their own health related issue and remain busy in family care. Maximum $40 \%$ of patients were educated up to primary level only; this may be because of their unawareness towards health care. Maximum 56.67\% were having increased micturition, may be due to the local irritation of the organ near by the cervical region, or the vitiation of apana vayu may cause the increase frequency of micturation. There was no definite relationship found between menstrual disturbances and cervical erosion. Observation related to parity showed that the incidence of the disease increases with the parity because $50 \%$ patients among study were having parity more than two this is because during child birth there is more chances of development of cervical erosion due to Akalevahamanaya. 70\% patients were of VK Prakriti, it deals with the causative Dosha involved in this disease was also Vata and Kapha so these patients were more prone to suffer from vitiation of Vata kapha dosha. 40\% patients had duration of illness was in between 1-2, this shows the chronicity nature of the disease, symptomless in starting but along with due course of time when associated with other complications, then only the patients visit a doctor. $53.33 \%$ were showing normal sized cervix, followed $46.67 \%$ patients were having hypertrophied cervix. Cervix become hypertrophied when there was any infection present as incidence of vaginal discharge, and maximum no. of patients were having mucoid discharge i.e. in maximum patient there were involvement of secondary infection was absent this direct related with condition of cervix i.e. it was normal in size. $66.67 \%$ were showing erosion on both lips of cervix, $53.33 \%$ were having erosion on cervix up to $25 \%$ area of the cervix, followed by $23.33 \%$ patients in whom the extent of erosion was between $26-50 \%$ and $51-75 \%$ which was probably due to the reason that generally the disease is symptomless in starting but along with due course of time when associated with other complications, then only the patients visit a doctor. Due to the chronicity of disease more area of cervix may be involved in erosion.

\section{Discussion of comparison of results between Group- A \& Group-B}

Vaginal discharge and extent of erosion: Out of total $30,100 \%$ patient complained for vaginal discharge and have eroded cervix. It may be due to the hyperplasia of cervical glands, which causes the excessive vaginal discharge and over growth of columnar epithelium which make cervix to look eroded. Corresponding to epithelization of cervical erosion the vaginal discharge was one of the symptoms also disappeared soon in more number of cases in group A. Use of the Udumbaradi taila probably prevented congestion or hyperamemia, thus prevented regeneration of superficial few columnar cell left over after destruction by Kusthadi churna and helped in better epithelization. Anti-inflammatory activities of Arka, Pippali, Kustha and Saindhava salt in the Kusthadi churna along with the Garbhashayashothahara, Stambhana and uterine tonic properties of Udumbaradi tail. The re-epithelization takes place rapidly on the destruction of the columnar epithelium. Most of drugs of Kusthadi churna have the anti-inflammatory, antiseptic and antimicrobial activities which helps in fast healing of the erosion area, which may helped in decrease vaginal secretion, and also prevent invasion of the microorganisms. Most of the drugs in Kusthadi churna having Deepana, Pachan properties, this may increase the metabolic activities of the cell and the generation of new DNA materials so that new squamous cell are formed. As the squamous cell formed properly the vaginal discharge will minimize.

Pruritis vulvae: This is because antimicrobial \& anti inflammatory activities was present in almost 80-90\% drugs of Udumbaradi taila. As the symptoms present in few patients ( 2 patients in group A and 6 patients in group B) in both group that's why the improvement was insignificant.

Dysmenorrhoea: Maximum percentage of relief was found in group A, this may be because of anti inflammatory activities were present in almost $80-90 \%$ drugs and uterine tonic effect of Udumbaradi taila, which may helps in decrease prostaglandin secretions which is major cause of the pain during menses.

Lower abdominal pain - Maximum percentage of improvement i.e. $80 \%$ was recorded in group A. Improvement was very significant in both the groups almost equal and differences were minimal, because in both the group the Sothahara, and anti-inflammatory drugs are present due to which the congestion in the lower abdomen is minimized. Improvement in group B is more because of the presence of the Arka and Pippali of Kusthadi churna which having the analgesic properties.

Fatigue - This is due to overall effect of Kusthadi churna and Udumbaradi taila pitchu which decreases in amount of vaginal discharge (Shweta pradar) which is also responsible for fatigue.

Joint Pain - Percentage of improvement i.e. $42.85 \%$ was recorded in group A and $34.28 \%$ in group B. This was probably due to virtue of Sukshma, Vyavayi and Vikasi properties of oil, due to these properties drug is easily absorbed thorough the mucosa when Taila used alone. The joint pain is produced by the effect of Vata. Tail is the best Vata shamaka, so it gives considerable relief in lower backache.

Oozing blood from erosion on rubbing with gauze piece: It was reduced in both groups and improvement was more in group A.

Changes in haematological investigations - In both the groups although some improvement was noticed i.e. group A followed by improvement in group B, but the result were not significant.

\section{CONCLUSION}

* Bahirparimarjan chikitsa in the form of Kusthadi churna and Udumbaradi taila pichu (group -A) is highly effective in disintegration of the pathogenesis of the disease. 
* Re-epithelisation occurs earlier when both the trial drugs Kusthadi churna and Udumbaradi taila pichu (Group A) are used in combination, it become more effective in removing of Karnika (nebothian follicles) and managing the associated chronic cervicitis as compared to the use of Udumbaradi taila pichu alone.

* No adverse effect or complications is produced with the use of this treatment. This is treatment is safe economic, non surgical, very effective and can be used for treatment of cervical erosion

* Better result was observed in Group-A, suggests that both the drugs Kusthadi churna and Udumbarad itaila pichu might have acted synergistically, the therapeutic effects are potentiated with the use of Udumbaradi taila pichu.

* Comparing the symptomatic improvement in both groups it was found that overall relief was highest in group-A than group-B. Hence it can be concluded that combined use of Kusthadi churna and Udumbaradi taila pichu is effectively helps in managing the disease cervical erosion. But in joint pain and low back pain the relief was seen well in group B.

* Infertility was not taken in assessment criteria of this trial. But it was observed that relief in infertility associated due to the erosion by this drug. Out of 30 registered patients 3 were conceived after the completion of trial. So the drug may be used for the treatment of infertility associated with cervical erosion.

\section{ACKNOWLEDGMENT}

Authors are thankful to Dr. Sushila Sharma, Associate professor Prasuti-Stree Roga, NIA and Dr. Hetal H. Dave, Lecturer, Prasuti-Stree Roga, NIA, Jaipur for their valuable guidance for the review and for their guidance to publish this manuscript.

\section{REFERENCES}

1. Charaka, Charaka Samhita, Chikitsa Sthana 30, Vol. 2, Commented By Shastri Kashinath And Chaturvedi Gorakhanath, Published By Chaukhambha Bharti Academy, Varanasi, Reprint Year 2003.

2. Kaviraj Ambikadutta Shastri. Ayurveda Tattva Sandipika Hindi commentary Vol 2 on Sushruta Samhita. Uttaratantra 33. 14th Ed. Varanasi: Chaukhamba Samskrita Samsthana; 2003.

3. Tiwari Premvati, Ayurvedia Prasutitantra Avam Striroga, Vol.2 Second Edition. Chaukamba Orientalia Varanasi;1999.

4. Dutta D.C, Text book of Gyanaecology. 5th Edition: revised reprint: 2009; Kolkata; New Central Book Agency (P) Ltd, 2008.

5. Herrison's principle of internal medicine, Mc Graw Hill Companies Publication, $16^{\text {th }}$ edition.

6. Howkins and Bourne, shaw's textbook of gynacology. Elsevier publications; $14^{\text {th }}$ edition 2008.

7. Dadlani Bharti ; Nidanatmaka Study of Karnini Yonivyapad with special reference to Chronic Cervicitis with Erosion 2003 , P.G. Deptt. of Rog Nidana \& Vikriti Vigyana, National Institute of Ayurveda

8. Kulkarni RN, Durge PM: Role of socioeconomic factors and cytology in cervical erosion in reproductive age group women: Indian J Med. Sci.2002,Dec. 56 (12) : 598-601

9. Berek \& Novak's Gynaecology, $14^{\text {th }}$ edition, edited by Jonathen S. Berek, Lippincott William \& Wilkins Publishers

10. http://www.google.com/derekeqplan.hmt site visited on 25 Dec. 2012.

\section{Cite this article as:}

Chaurasia Ranju Kumari, C.M. Jain, B. Pushplatha, K. Bharathi. Clinical Evaluation of Efficacy of Kusthadi Churna with Udumbaradi Taila in the Management of Karnini Yonivyapad w.s.r. to Cervical Erosion. International Journal of Ayurveda and Pharma Research. 2015;3(12):58-64. Source of support: Nil, Conflict of interest: None Declared
*Address for correspondence Dr. Ranju Kumari Chaurasia

P.G. Scholar, Department of Prasuti-Stree Roga National Institute of Ayurveda, Jaipur.

E mail: ranju.chaurasia@gmail.com 